\title{
Comparison Between Presence of Epstein Barr Virus in Nodal and Extra Nod- al Diffuse Large B Cell Lymphoma of Head and Neck, an Iranian Experience
}

\author{
Mohammad Javad Ashraf ${ }^{1}$, Alireza Makarempour ${ }^{1}$, Ahmad Monabati ${ }^{1}$, Negar Azarpira ${ }^{1, *}$, \\ Bijan Khademi ${ }^{2}$, Afsoon Hakimzadeh ${ }^{1}$, Elham Abedi ${ }^{1}$, Bita Valibeigi ${ }^{1}$ \\ ${ }^{1}$ Transplant Research Center, Department of Pathology, Shiraz Medical School, Shiraz University of Medical Sciences, Shiraz, IR Iran \\ ${ }^{2}$ Department of Otolaryngology, Shiraz Medical School, Shiraz University of Medical Sciences, Shiraz, IR Iran \\ * Corresponding author: Negar Azarpira, Transplant Research Center, Department of Pathology, Shiraz Medical School, Shiraz University of Medical Sci- \\ ences, Shiraz, IR Iran. Tel.: +98-7116474331, Fax:+98-7116474331, E-mail:negarazarpira@yahoo.com
}

A B S T R A C T

Background: Epstein Barr Virus (EBV) is one of the most common viral infections in human population. EBV has a significant role in pathogenesis of Hodgkin's lymphoma, Burkitt's lymphoma and nasopharyngeal carcinoma. The role of EBV in non-Hodgkin's lymphoma, diffuse large B cell (NHL- DLBL) in the head and neck is controversial.

Objectives: The purpose of this study is to find out the difference between the presence of Epstein Barr virus in nodal and extra nodal lymphoma of head and neck.

Patients and Methods: A total of 30 cases of DLBL in two separate groups were collected from pathology department. The first group was consisted of 15 patients with DLBL of neck lymph node and the other was consisted of 15 patients with extra nodal DLBL of head and neck mainly in palatine tonsil. Both immune-histo-chemical (IHC) study and polymerase chain reaction (PCR) for detection of late membrane antigen(LMP) were performed on formalin fixed paraffin embedded tissue.

Results: All 30 cases were negative for EBV in IHC method. But in PCR method, $10 \%$ of patients were positive for LMP gene. There were 2 positive cases in nodal lymphoma and 1 positive case in extra nodal lymphoma group.

Conclusions: Compare with PCR method, it seems that IHC is not a sensitive method for detection of EBV. Overall, the finding of EBV in NHL depends on site, type of lymphoma and the detection method.

Keywords: Epstein-Barr Virus Infections; Lymphoma, Non-Hodgkin; Antigens; Head and Neck

Copyright @ 2012, Iranian Red Crescent Medical Journal; Published by Kowsar Corp.

\section{Background}

Epstein bar virus (EBV) or human herpes virus 4 (HHV4), belongs to DSDNA virus from herpesviridae family, is a worldwide viral infection. EBV infects nearly all humans and persists for the life of the host. EBV was first isolated in 1964 by Epstein et al. (1) from African Burkitt's lymphoma cell lines and estimated prevalence in the total human populations of $80-90 \%$. Close personal contact is usually required for transmission "kissing disease".
In developing countries, the infection occurs at a much earlier age so that $90 \%$ of children over the age of 2 are seropositive. The virus infects squamous epithelial cells as well as B lymphocytes via the complement receptor, CR2 (CD21). EBV contains receptors identical to C3d receptors. It can induce infectious mononucleosis, Hodgkin's lymphoma, Burkitt's lymphoma, nasopharyngeal carcinoma and post-transplantlympho-proliferative disease. It has Also a role in chronic fatigue syndrome, dermatomyositis

Article type: Research Article; Received: 26 May 2011, Revised: 26 Aug 2011, Accepted: 27 Aug 2011; DOI: 10.5812/ircmj.1302

Implication for health policy/practice/research/medical education:

This study is going to find out the difference between the presence of Epstein Barr virus in nodal and extra nodal lymphoma of head and neck.

Please cite this paper as:

Ashraf MJ, Makarempour A, Monabati A, Azarpira N, Khademi B,Hakimzadeh A, et al. Comparison Between Presence of Epstein Barr Virus in Nodal and Extra Nodal Diffuse Large B Cell Lymphoma of Head and Neck, an Iranian Experience. Iran Red Cres Med J. 2012;14(12):764-70. DOI: 10.5812/ircmj.1302 
and multiple sclerosis. EBV has also been linked to a variety of other epithelial and lymphoid derived proliferative diseases, including thymic carcinoma (2), gastric carcinoma (3), oral hairy leukoplakia, non-Hodgkin's lymphoma of B cell origin (3) and Hodgkin's disease occurring in immune compromised patients. Generally, the rate of EBV infection in Hodgkin's lymphoma is higher than non-Hodgkin's lymphoma $(4,5)$. The possible mechanism of EBV role in inducing lymphoma is interfering with normal function of P53 that regulate normal apoptosis, so it can lead to sustained genetic damage. Non-Hodgkin's lymphoma (NHL) is a malignancy that arises from lymphoid tissue. In the United States, NHL is the fifth most commonly diagnosed cancer. About $30-40 \%$ of all malignant lymphoma arise primarily from extranodal sites. The most frequent sites of extra nodal lymphoma are gastrointestinal tract and the upper aero digestive tract (6). This disease is more common in men than in women and affects whites more often than African Americans or Asian Americans (7). NHL can occur at all age groups, however, it is more frequent in the elderly than in younger patients. The incidence of T-cell NHL is higher in Far East Asia countries than in Western and developed countries (8). Extra nodal head and neck lymphoma show a wide variability in morphology, anatomic location, the rate of EBV infection and prognosis depend on geographic places. For example NHL of Sino nasal tract is higher in south East Asian countries, most of them are NK/T cell variant, express CD56 in immunephenotyping study and distinctly have an aggressive behavior and higher rate of EBV infection in compare with the same lymphoma in western countries (9). These variations among different populations suggest an interaction of environmental factors such as EBV as an oncogenic virus (10). NHL is more common among people who have abnormal or compromised immune systems, such as those with inherited immune deficiencies, individuals with autoimmune disorders, AIDS and people taking immunosuppressant drugs following organ transplants $(5,11)$. EBV is associated with post-transplantlympho proliferative disorders (PTLD) (11). Drinking water contaminated with nitrate and smoking may increase the risk of NHL (12,13). Diffuse large B cell lymphoma (DLBL) is one the most common sub type of NHL worldwide. The disease frequently presents as a rapidly enlarging lymph node in 50\%. The site is extra nodal in up to $40 \%$ of affected patients. In practice, DLBL is diagnosed by morphology and positivity for CD20 (mature B-cell marker) and CD79a (pan-B-cell marker). CD10 is expressed in $25-50 \%$ of cases and CD5 is expressed in a small proportion $(14,15)$. The proliferation index, measured by Ki-67 expression, is usually higher than $40 \%$ to $50 \%$, and values greater than $80 \%$ may be associated with a worse outcome (16).

\section{Objectives}

The purpose of this study is to find out the difference between the presence of Epstein Barr virus in nodal and extra nodal lymphoma of head and neck.

\section{Patients and Methods}

A total of 30 cases of lymphomas (DLBL) in head and neck region were collected from pathology departments of Khalili, Faghihi and Nemazi hospital, affiliated to Shiraz University of Medical Sciences, from 2003 to 2009. None of them had history of immunosuppression. The study was approved by the ethics committee of Shiraz University of Medical Sciences. All patients were from the same geographic region (southern Iran). The slides and reports were reviewed by 3 independent pathologists. Among them, 15 cases belonged to category of nodal lymphoma (NL-NHL) and 15 cases belonged to extra nodal lymphoma of head and neck region (EN-NHL) ( Figures 1, 2 ). The immunohistochemical (IHC) markers which were used for diagnosing, composed of leukocyte common antigen (LCA, CD45), CD20 and CD79 (as a common B cell marker), CD3 (as a T cell marker), Ki67 (MIB-1), (as a proliferative index) and cytokeratin (CK) as an epithelial marker for rule out of metastasis. All primary antibodies were purchased from Dako, Denmark. Envision Dual link system-HRP (ready to use, Dako) was used as the secondary antibody. Incubation with 3,3-diaminobenzidine tetrahydrochloride as a chromogen substrate solution produced brown color. IHC and polymerase chain reaction (PCR) were used as two different methods for detection of EBV in paraffin sections. Latent membrane protein -1 (LMP-1, DAKO Denmark) was used as primary antibody for detection of EBV. For PCR, DNA was extracted manually by using xylol (for deparafinising), serial dilutions of ethanol (for tissue rehydration) and lysis buffer (EDTA, SDS10\%, Proteinase K and Tris HCL $1 \mathrm{M})$. The $\beta$-gloubin was used as internal control.

Forward primer: 5' CCA GAC AGC AGC CAATTG TC 3' Reverse primer: 5' GGT AGA AGA CCC CCT CTT AC 3'

(MOLBIOL company, Berlin) were used for amplification of 129 bp of LMP-1 gene. The region was amplified with a Mastercycler (Eppendorff, Germany),

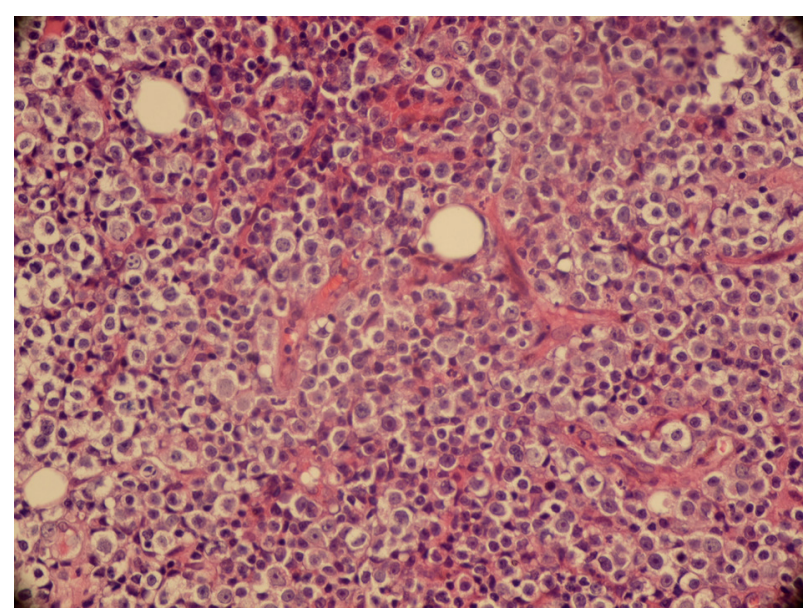

Figure 1. Sheet of DiscohesiveLarge Tumor Cell Infiltrated the Normal Parenchyma (H\&E × 200) 


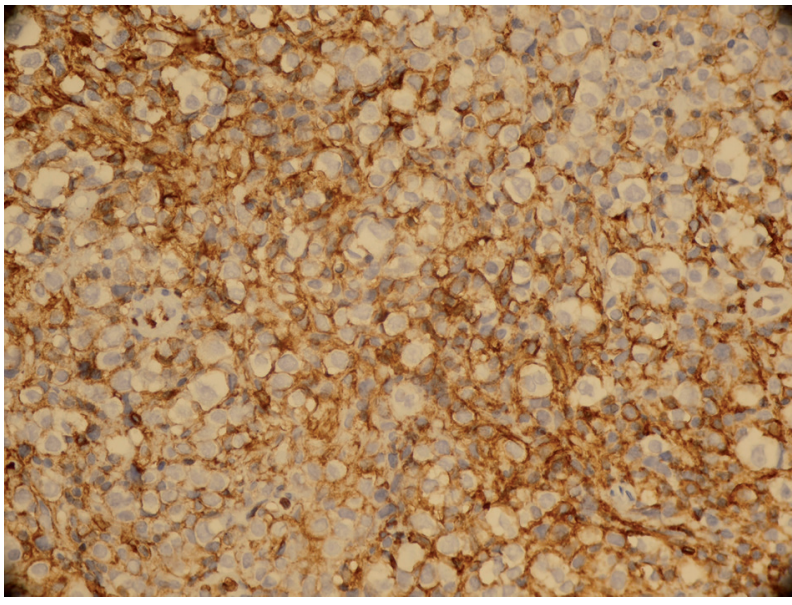

Figure 2. Positive Immunostaining for CD $20(\mathrm{IHC} \times 200)$

(35 cycles of $94{ }^{\circ} \mathrm{C}$ for $60 \mathrm{~s}, 60{ }^{\circ} \mathrm{C}$ for $60 \mathrm{~s}$, and $72{ }^{\circ} \mathrm{C}$ for $1 \mathrm{~min})$, in a $25 \mu \mathrm{l}$ reaction solution containing $0.5 \mu \mathrm{g}$ genomic DNA, 1× PCR buffer, $0.3 \mathrm{mM} \mathrm{MgCl}$, $0.3 \mathrm{mMdNTPs}$, $2 \mathrm{U}$ Taq DNA polymerase (Cinagene, Iran) and $0.3 \mu \mathrm{mol}$ of each primer.

\section{Result}

All of the patients were Iranian including 16 men and 14 women, with mean average age of 53.5 years (Range from 9 to 81 years). The ratio of male to female was 8 to 7 . By considering group, in nodal lymphoma there were 9 men and 6 women with mean average ages of 51 years (Range 980 years). In extra nodal group, 7 men and 8 women with mean average ages of 56 years (Ranges 16- 81 years) were included. The clinical presentation of nodal lymphoma was neck mass and another group presented with symptoms like dysphasia or hearing loss. The primary site of all nodal lymphoma was cervical lymph nodes; where in extra nodal group, palatine tonsil and Sino nasal region were the primary site of 12 and 3 patients respectively. The tumor cells were positive for CD20 (Figures 1 and 2), CD79 and CD45 in large cells and negative for CK and CD3. The range of Ki67 positivity was $20-90 \%$. In IHC, all patients were negative LMP-1 antigen. By using PCR method to amplify the LMP gene of EBV, we had 3 (10\%) positive cases. Two cases belonged to nodal lymphoma and 1 case to extra nodal group ( Tables 1, 2).

\begin{tabular}{|c|c|c|c|c|c|c|c|c|}
\hline Case & Age & Sex & Site & Type & Ki67 & Ki67 score & $\mathbf{P C R}^{\mathrm{a}}$ & IHC $^{\mathrm{a}}$ \\
\hline 1 & 17 & F & NECK L.N ${ }^{\mathrm{a}}$ & $\operatorname{DLBL}^{\mathrm{a}}$ & $90 \%$ & 4 & - & - \\
\hline 2 & 56 & $\mathrm{~F}$ & NECK L.N & DLBL & $30 \%$ & 2 & - & - \\
\hline 3 & 77 & M & NECK L.N & DLBL & $90 \%$ & 4 & - & - \\
\hline 4 & 11 & M & NECK L.N & DLBL & $20 \%$ & 2 & - & - \\
\hline 5 & 42 & M & NECK L.N & DLBL & $40 \%$ & 3 & - & - \\
\hline 6 & 80 & $\mathrm{~F}$ & NECK L.N & DLBL & $80 \%$ & 4 & - & - \\
\hline 7 & 76 & M & NECK L.N & DLBL & $40 \%$ & 3 & - & - \\
\hline 8 & 71 & $\mathrm{~F}$ & NECK L.N & DLBL & $80 \%$ & 4 & + & - \\
\hline 9 & 72 & F & NECK L.N & DLBL & $70 \%$ & 4 & - & - \\
\hline 10 & 46 & M & NECK L.N & DLBL & $60 \%$ & 3 & - & - \\
\hline 12 & 23 & M & NECK L.N & DLBL & $70 \%$ & 4 & + & - \\
\hline 13 & 55 & M & NECK L.N & DLBL & $80 \%$ & 4 & - & - \\
\hline 14 & 74 & $\mathrm{~F}$ & NECK L.N & DLBL & $70 \%$ & 4 & - & - \\
\hline 15 & 9 & M & NECK L.N & DLBL & $90 \%$ & 4 & - & - \\
\hline
\end{tabular}

a Abbreviations: L.N: Lymph node, DLBL: Diffuse Large B cell Lymphoma, IHC: Immunohistochemical Study, PCR: Polymerase Chain Reaction

\section{Discussion}

EBV has been associated with a number of malignant lymphoma including Hodgkin, non-Hodgkin, Burkitt's and post-transplant B-cell lymphoma. Although most of these lymphomas have B-cell origin, the EBV genome has been detected in T-cell lymphomas especially when it originates from nasal cavity $(17,18)$. The role of EBV in pathogenesis of NHL was evaluated in different parts of the world ( Table 3 ). The rate of EBV positivity and its role as an etiology is dependent to 5 major factors:
1. The state of patient's immunity (Immunocompromised or immunocompetent)

2. The method of EBV Detection (IHC, PCR and ISH-EBER)

3. The type of lymphoma (Hodgkin's versus non-Hodgkin's) and Lymphoma subtypes (B-cell, T-cell, NK-cell, MALTOMA, etc.)

4. The anatomic site of lymphoma (Sino-nasal, head and neck, gastro intestinal tract, etc)

5-The geographic region of study (South East Asia versus Europe and North America) 


\begin{tabular}{|c|c|c|c|c|c|c|c|c|}
\hline Case & Age & Sex & Site & Type & Ki67 & Ki67 score & $\mathbf{P C R}^{\mathrm{a}}$ & IHC $^{\mathrm{a}}$ \\
\hline 1 & 64 & F & sinonasal & $\mathrm{DLBL}^{\mathrm{a}}$ & $80 \%$ & 4 & - & - \\
\hline 2 & 40 & $\mathrm{~F}$ & Palatine tonsil & DLBL & $40 \%$ & 3 & - & - \\
\hline 3 & 76 & M & Palatine tonsil & DLBL & $20 \%$ & 2 & - & - \\
\hline 4 & 65 & $\mathrm{~F}$ & Palatine tonsil & DLBL & $30 \%$ & 2 & + & - \\
\hline 5 & 50 & M & Palatine tonsil & DLBL & $60 \%$ & 3 & - & - \\
\hline 6 & 32 & M & Palatine tonsil & DLBL & $80 \%$ & 4 & - & - \\
\hline 7 & 66 & $\mathrm{~F}$ & Palatine tonsil & DLBL & $70 \%$ & 4 & - & - \\
\hline 8 & 74 & $\mathrm{~F}$ & Palatine tonsil & DLBL & $80 \%$ & 4 & - & - \\
\hline 9 & 80 & $\mathrm{~F}$ & Palatine tonsil & DLBL & $80 \%$ & 4 & - & - \\
\hline 10 & 70 & M & Palatine tonsil & DLBL & $70 \%$ & 4 & - & - \\
\hline 12 & 56 & F & Palatine tonsil & DLBL & $90 \%$ & 4 & - & - \\
\hline 13 & 16 & M & sinonasal & DLBL & $10 \%$ & 1 & - & - \\
\hline 14 & 23 & M & sinonasal & DLBL & $70 \%$ & 4 & - & - \\
\hline 15 & 41 & M & Palatine tonsil & DLBL & $90 \%$ & 4 & - & - \\
\hline
\end{tabular}

a Abbreviations: DLBL: Diffuse large B cell lymphoma, IHC: Immunohistochemical study, PCR: Polymerase Chain Reaction

\subsection{State of Immunity}

In 1999, Calzolari et al. (19) demonstrated that EBV infection is highly associated with NHL of the head and neck in HIV-infected patients. Their data suggested that LMP-1 expression may cause p53 loss of function even in the absence of p53 gene mutations, as assessed by SSCP. Similarly, Leong et al. (20) reported that all immunosuppressed patients with large B-cell oral lymphoma had EBV infection in compare with only $9 \%$ of immunocompetent patients. In 2001, Leong et al. (21) showed the strong concordance between EBV infection and NHL of oral cavity in immunosuppressed patients, all of the 9 immunosuppressed patients were positive for EBV (100\%) whereas only $34 \%$ of immunocompetent patients were positive for EBV with ISH-EBER method. (21). In 2004, Iamproon et al. (19) in Thailand studied on 5 cases of immunosuppressed and 6 cases of immune competent NHL and showed all of immunosuppressed patients were positive for EBV by ISH method whereas only $40 \%$ of immune competent patients were positive for EBV. These studies are in agreement with our study. The result of our study on $30 \mathrm{im}$ muno competent patients with lymphoma show only $13 \%$ EBV positive in nodal lymphoma and 7\% EBV positive in extranodal lymphoma by PCR method.

\subsection{Method of EBV Detection}

In 1997, Van de Rijn in Guatemala studied on 17 cases of Sino nasal lymphoma and 16 cases of non-Sino nasal lymphoma in head and neck region by two methods of IHC and ISH-EBER(22). They showed significant difference in results depend to the method. (5\% in IHC method and 38\% in EBV (Epstein-Bar Virus)-Encoded RNA (Ribonucleic Acid). In Situ Hybridization, (EBER-ISH) method).
The study is in agreement with our study that shows IHC method as an unreliable method for detecting EBV in NHL of head and neck. Mitarnun in Thailand studied on 60 cases of extranodal lymphoma and found that, ISH-EBER was a sensitive method for detection of EBV (23). The similar study with the same results was done by Martinez et al. (24) in Peru (1999). Bahnassy et al. (25) studied on 50 cases of EN-NHL of head and neck in Egypt. They used two methods of EBV detection e.g; PCR and ISH-EBER. The positive results with PCR and EBER-ISH were 70\% and 90\% respectively.

They explained although both methods were highly sensitive techniques but the difference between the results was attributed to difficulty in obtaining good-quality amplifiable DNA from paraffin-embedded tissues, heterogeneity of tumors and the ratio of tumor/normal cells. In another study more than 95\% concordance was detected between PCR results and EBER-ISH for detection of $\operatorname{EBV}(26,27)$. Leong et al. $(21,28)$ suggested that the EBER-ISH method was the most sensitive method for EBV detection. The sensitivity of PCR for EBV detection depends on part of EBV genomes which chose as a target for amplification. It is supposed that the most sensitive gene is BamH1W (21).

\subsection{The Type of Lymphoma}

Ko et al. (29) found that $54 \%$ of T-cell lymphoma (TCL) was positive in Korea. Mitranun (23) in Thailand showed all of the 19 cases of TCL were positive for EBV by ISH-EBER method. The similar results were seen in Tai et al. (24) study in Thailand and Martinez et al. in Peru (6). Francesco D amore et al. (4) studied on 374 cases of non-Hodgkin's lymphoma of DLBL type in Denmark. They showed 


\begin{tabular}{|c|c|c|c|c|c|c|c|}
\hline Reference & Year & Country & Site & Subtype & Number & Method & $\begin{array}{l}\text { Result (\% } \\
\text { positive for } \\
\text { EBV) }\end{array}$ \\
\hline \multirow{2}{*}{ Ko et al. (31) } & \multirow[t]{2}{*}{2004} & \multirow[t]{2}{*}{ Korea } & \multirow[t]{2}{*}{ ENNHLa } & \multirow[t]{2}{*}{ TCLa } & \multirow[t]{2}{*}{11} & ISH- EBERa & $54 \%$ \\
\hline & & & & & & PCR & $0 \%$ \\
\hline \multirow{4}{*}{ Mitarnun et al. (24) } & \multirow[t]{4}{*}{2006} & \multirow[t]{4}{*}{ Thailand } & Sino nasal & $89 \% \mathrm{TCL}$ & 16 & \multirow{4}{*}{ ISH - EBER } & $100 \%$ \\
\hline & & & \multirow{3}{*}{ Nasopharynx } & $11 \% \mathrm{BCL}$ & 2 & & $0 \%$ \\
\hline & & & & $17 \% \mathrm{TCL}$ & 7 & & $100 \%$ \\
\hline & & & & $83 \% \mathrm{BCL}$ & 35 & & $5.4 \%$ \\
\hline \multirow{2}{*}{ Feng et al.(33) } & \multirow[t]{2}{*}{2007} & \multirow[t]{2}{*}{ China } & \multirow[t]{2}{*}{ Sino nasal } & DLBLa & 6 & \multirow{2}{*}{$\begin{array}{l}\text { PCR and ISH } \\
\text { For all cases }\end{array}$} & $0 \%$ \\
\hline & & & & NKCa/T cell & 44 & & $100 \%$ \\
\hline Tai et al. (6) & 2004 & Thailand & Sino nasal & NKC/T cell & 20 & PCR & $100 \%$ \\
\hline $\begin{array}{l}\text { Quintanilla-Martinez et al. } \\
\text { (25) }\end{array}$ & 1999 & Peru & Sino nasal & NKC/T cell & 28 & ISH-EBER & $90 \%$ \\
\hline van de Rijn et al.(23) & 1997 & $\begin{array}{l}\text { Guate- } \\
\text { mala }\end{array}$ & Sino nasal & $\begin{array}{l}\text { Head and } \\
\text { neck }\end{array}$ & 17 & ISH-EBER & $38 \%$ \\
\hline \multirow{3}{*}{ Bahnassy et al (35) } & \multirow[t]{3}{*}{2006} & \multirow[t]{3}{*}{ Egypt } & \multirow{3}{*}{$\begin{array}{l}\text { EN-NHL head } \\
\text { and neck }\end{array}$} & $62 \%$ B-cell & \multirow[t]{3}{*}{50} & PCR & $70 \%$ \\
\hline & & & & $18 \%$ T-cell & & ISH-EBER & $90 \%$ \\
\hline & & & & 20\% Nk-cell & & & \\
\hline \multirow{2}{*}{ Ko et al. (31) } & \multirow[t]{2}{*}{1994} & \multirow[t]{2}{*}{ Korea } & \multirow[t]{2}{*}{ NHL } & TCL & \multirow[t]{2}{*}{50} & \multirow[t]{2}{*}{ ISH-EBER } & $61 \%$ \\
\hline & & & & BCLa & & & $24 \%$ \\
\hline Calzolari et al.(19) & 1998 & Italy & $\begin{array}{l}\text { Oral NHL (HIV } \\
\text { Patients) }\end{array}$ & DLBL & 6 & ISH-EBER & $100 \%$ \\
\hline \multirow{8}{*}{ Leong et al. (21) } & \multirow[t]{8}{*}{2001} & \multirow[t]{8}{*}{ Canada } & Oral NHL & All subtypes & 9 Immuno & ISH-EBER & $100 \%$ \\
\hline & & & & & $\begin{array}{l}\text { compra- } \\
\text { mised }\end{array}$ & IHC-LMP & $62 \%$ \\
\hline & & & & & 46 Immuno & ISH-EBER & $34 \%$ \\
\hline & & & & & competent & IHC-LMP & $10 \%$ \\
\hline & & & & DLBL & 22 Immuno & ISH-EBER & $27 \%$ \\
\hline & & & & & compramis & IHC-LMP & $9 \%$ \\
\hline & & & & & 3 Immuno & ISH-EBER & $100 \%$ \\
\hline & & & & & competent & IHC-LMP & $100 \%$ \\
\hline & 2006 & Thailand & NHL & $\mathrm{BCL}$ & 100 & ISH-EBER & $13 \%$ \\
\hline Mitarnun et al. (24) & & & & TCL & 100 & ISH-EBER & $51 \%$ \\
\hline & & & & $\mathrm{CHL}$ & 100 & ISH-EBER & $64 \%$ \\
\hline Takrare et al (20) & 2004 & Japan & NHL & NK/TCL & 32 & ISH-EBER & $96 \%$ \\
\hline & & & & & & PCR & $48 \%$ \\
\hline
\end{tabular}

a Abbreviations: TCL: T- cell lymphoma, BCL: B cell lymphoma, NKC: Natural killer cell, EN-NHL: Extra Nodal Non-Hodgkin’s lymphoma, DLBL: Diffuse large B cell lymphoma, ISH-EBER: In Situ Hybridization -EBV (Epstein-Bar Virus)-Encoded RNA (Ribonucleic Acid)

that only $7 \%$ of cases were positive for EBV by RNA-ISH method. Mitranun et al. (16) studied on 35 cases of nasopharyngeal B-cell lymphoma in Thailand. They found only 5.4\% positivity for EBV. They also studied on 300 cases of lymphoma (100 cases of BCL, 100 cases of TCL and 100 cases of $\mathrm{CHL}$ ). The rate of EBV infection by EBER-ISH method was $13 \%, 51 \%$ and $64 \%$ respectively (30). Feng Y F et al. (31)studied on 6 cases of DLBL of Sino nasal lymphoma in China. All of them were negative for EBV (PCR and ISH). Takahara et al. (32) found the EBV-encoded small nuclear early region (EBER) RNA in 96\% of tumors. Above mentioned studies revealed that $\mathrm{EBV}$ has more potent role in inducing T-cell and NK-cell lymphoma rather than B-cell lymphoma. This finding is in agreement with our study that shows $10 \% \mathrm{EBV}$ positive in NHL- DLBL. 


\subsection{The Anatomic Site of Lymphoma}

The Sino nasal region was the most common sites for EBV associated lymphoma in head and neck region in several studies. Mitranun et al. showed that all of the 16 cases of lymphoma in Sino nasal region were positive for EBV. The same result was obtained in another study by Feng et al. $(23,31)$ on 44 cases of Sino nasal lymphoma. Tai et al. (24) in Thailand and Martinez et al. (6) in Peru showed the high prevalence of EBV infection in Sino nasal lymphoma. 127 cases of lymphoma from different anatomical sites were studied by Yang et al. (33) and high prevalence of EBV infection was found in nasopharyngeal area.

\subsection{The Geographic Region Which Study Were Done}

The rate of EBV in lymphomatous tissue in a specific geographic region is dependent to the overall rate of EBV infection in that region. Bahnassy et al. (34) in 2006 in Egypt showed 90\% EBV positive in their lymphoma of head and neck region. They explained this high frequency of EBV infection in extra nodal lymphoma could be due to relatively high frequency of EBV infection in normal Egyptian population, since they detected EBV DNA in $40 \%$ of their normal samples. There is high prevalence of EBV associated lymphoma in counties like China and Korea. The high prevalence of EBV infection in their populations can explain this concordance. $(6,23)$. Vannarat et al. (35) claimed that, the EBV strains distribution may be associated with geographic/ethnic and clinical outcomes in the Thai population. Certain EBV strains defined by their LMP1 sequence may influence cell tropism, disease association, or disease severity. It seems that IHC is not a sensitive method for detection of EBV as compare with PCR. The finding of EBV in NHL depends on site, type of lymphoma and detection method. The attribute factors such as heterogeneity of tumors, the ratio of tumor/ normal cells and the presence of EBV particles in normal homing lymphocytes are attributed for different results, when using different methods.

\section{Acknowledgements}

None declared.

\section{Financial Disclosure}

None declared.

\section{Funding/Support}

None declared.

\section{References}

1. Shah KM, Young LS. Epstein-Barr virus and carcinogenesis: beyond Burkitt's lymphoma. Clin Microbiol Infect. 2009;15(11):982-8.

2. Leyvraz S, Henle W, Chahinian AP, Perlmann C, Klein G, Gordon RE, et al. Association of Epstein-Barr virus with thymic carcinoma. N Engl J Med.1985;312(20):1296-9.
3. Imai S, Koizumi S, Sugiura M, Tokunaga M, Uemura Y, Yamamoto N, et al. Gastric carcinoma: monoclonal epithelial malignant cells expressing Epstein-Barr virus latent infection protein. Proc Natl Acad Sci U S A. 1994;91(19):9131-5.

4. d'Amore F, Johansen P, Houmand A, Weisenburger DD, Mortensen LS. Epstein-Barr virus genome in non-Hodgkin's lymphomas occurring in immunocompetent patients: highest prevalence in nonlymphoblastic T-cell lymphoma and correlation with a poor prognosis. Danish Lymphoma Study Group, LYFO. Blood. 1996;87(3):1045-55.

5. Garber K. Lymphoma rate rise continues to baffle researchers. J Natl Cancer Inst. 2001;93(7):494-6.

6. Tai YC, Kim LH, Peh SC. High frequency of EBV association and 30bp deletion in the LMP-1 gene in CD56 lymphomas of the upper aerodigestive tract. Pathol Int. 2004;54(3):158-66.

7. Lopez-Guillermo A, Colomo L, Jimenez M, Bosch F, Villamor N, Arenillas L, et al. Diffuse large B-cell lymphoma: clinical and biological characterization and outcome according to the nodal or extranodal primary origin. J Clin Oncol. 2005;23(12):2797-804.

8. Ko OB, Lee DH, Kim SW, Lee JS, Kim S, Huh J, et al. Clinicopathologic characteristics of T-cell non-Hodgkin's lymphoma: a single institution experience. Korean J Intern Med. 2009;24(2):128-34.

9. Chan JK, Yip TT, Tsang WY, Ng CS, Lau WH, Poon YF, et al. Detection of Epstein-Barr viral RNA in malignant lymphomas of the upper aerodigestive tract. Am J Surg Pathol.1994;18(9):938-46.

10. Gires O, Zimber-Strobl U, Gonnella R, Ueffing M, Marschall G, Zeidler $\mathrm{R}$, et al. Latent membrane protein 1 of Epstein-Barr virus mimics a constitutively active receptor molecule. EMBO J. 1997;16(20):6131-40

11. Gutierrez-Garcia G, Colomo L, Villamor N, Arenillas L, Martinez A Cardesa T, et al. Clinico-biological characterization and outcome of primary nodal and extranodal diffuse large B-cell lymphoma in the rituximab era. Leuk Lymphoma. 2010;51(7):1225-32.

12. Linet MS, McLaughlin JK, Hsing AW, Wacholder S, Co Chien HT, Schuman LM, et al. Is cigarette smoking a risk factor for nonHodgkin's lymphoma or multiple myeloma? Results from the lutheran brotherhood cohort study. Leukemia Research. 1992;16(67):621-4.

13. Ward MH, Cerhan JR, Colt JS, Hartge P. Risk of non-Hodgkin lymphoma and nitrate and nitrite from drinking water and diet. Epidemiology. 2006;17(4):375-82.

14. Lossos IS, Alizadeh AA, Diehn M, Warnke R, Thorstenson Y, Oefner PJ, et al. Transformation of follicular lymphoma to diffuse largecell lymphoma: alternative patterns with increased or decreased expression of c-myc and its regulated genes. Proc Natl Acad Sci $U$ S A. 2002;99(13):8886-91.

15. Matolcsy A, Chadburn A, Knowles DM. De novo CD5-positive and Richter's syndrome-associated diffuse large B cell lymphomas are genotypically distinct. Am J Pathol.1995;147(1):207-16.

16. Miller TP, Grogan TM, Dahlberg S, Spier CM, Braziel RM, Banks PM et al. Prognostic significance of the Ki-67-associated proliferative antigen in aggressive non-Hodgkin's lymphomas: a prospective Southwest Oncology Group trial. Blood. 1994;83(6):1460-6.

17. Anagnostopoulos I, Herbst H, Niedobitek G, Stein H. Demonstration of monoclonal EBV genomes in Hodgkin's disease and Ki1-positive anaplastic large cell lymphoma by combined Southern blot and in situ hybridization. Blood.1989;74(2):810-6.

18. Jones JF, Shurin S, Abramowsky C, Tubbs RR, Sciotto CG, Wahl $\mathrm{R}$, et al. T-cell lymphomas containing Epstein-Barr viral DNA in patients with chronic Epstein-Barr virus infections. N Engl J Med. 1988;318(12):733-41.

19. Iamaroon A, Pongsiriwet S, Mahanupab P, Kitikamthon R, Pintong J. Oral non-Hodgkin lymphomas: studies of EBV and p53 expression. Oral Dis. 2003;9(1):14-8.

20. Hartig G, Montone K, Wasik M, Chalian A, Hayden R. Nasal T-cell lymphoma and the lethal midline granuloma syndrome. Otolaryngol Head Neck Surg. 1996;114(4):653-6.

21. Leong IT, Fernandes BJ, Mock D. Epstein-Barr virus detection in non-Hodgkin's lymphoma of the oral cavity: an immunocytochemical and in situ hybridization study. Oral Surg Oral Med Oral Pathol Oral Radiol Endod. 2001;92(2):184-93. 
22. van de Rijn M, Bhargava V, Molina-Kirsch H, Carlos-Bregni R, Warnke RA, Cleary ML, et al. Extranodal head and neck lymphomas in guatemala: High frequency of epstein-barr virus-associated sinonasal lymphomas. Human pathology.1997;28(7):834-9.

23. Mitarnun W, Suwiwat S, Pradutkanchana J. Epstein-Barr virusassociated extranodal non-Hodgkin's lymphoma of the sinonasal tract and nasopharynx in Thailand. Asian Pac J Cancer Prev. 2006;7(1):91-4.

24. Quintanilla-Martinez L, Franklin JL, Guerrero I, Krenacs L, Naresh KN, Rama-Rao C, et al. Histological and immunophenotypic profile of nasal NK/T cell lymphomas from Peru: High prevalence of p53 overexpression. Human pathology.1999;30(7):849-55.

25. Chiang AK, Wong KY, Liang AC, Srivastava G. Comparative analysis of Epstein-Barr virus gene polymorphisms in nasal T/NK-cell lymphomas and normal nasal tissues: implications on virus strain selection in malignancy. Int J Cancer. 1999;80(3):356-64.

26. Haque T, Crawford DH. PCR amplification is more sensitive than tissue culture methods for Epstein-Barr virus detection in clinical material. J Gen Virol. 1997;78(Pt 12):3357-60.

27. Hassan R, White LR, Stefanoff CG, de Oliveira DE, Felisbino FE, Klumb CE, et al. Epstein-Barr virus (EBV) detection and typing by PCR: a contribution to diagnostic screening of EBV-positive Burkitt's lymphoma. Diagn Pathol. 2006;1(17).

28. Ryan JL, Fan H, Glaser SL, Schichman SA, Raab-Traub N, Gulley ML. Epstein-Barr virus quantitation by real-time PCR targeting multiple gene segments: a novel approach to screen for the virus in paraffin-embedded tissue and plasma. J Mol Diagn. 2004;6(4):378-85.
29. Ko YH, Cho EY, Kim JE, Lee SS, Huh JR, Chang HK, et al. NK and NK-like T-cell lymphoma in extranasal sites: a comparative clinicopathological study according to site and EBV status. Histopathology. 2004;44(5):480-9.

30. Saechan V, Mori A, Mitarnun W, Settheetham-Ishida W, Ishida T. Analysis of LMP1 variants of EBV in Southern Thailand: evidence for strain-associated T-cell tropism and pathogenicity. J Clin Virol. 2006;36(2):119-25.

31. Feng YF, Wu QL, Zong YS. Correlation of immunophenotype of sinonasal non-Hodgkin's lymphoma to Epstein-Barr virus infection. Ai Zheng. 2007;26(11):1170-6.

32. Takahara M, Kishibe K, Bandoh N, Nonaka S, Harabuchi Y. P53, $\mathrm{N}$ - and $\mathrm{K}$-Ras, and beta-catenin gene mutations and prognostic factors in nasal NK/T-cell lymphoma from Hokkaido, Japan. Hum Pathol. 2004;35(1):86-95.

33. Zhang Y, Peng J, Tang Y, He J, Zhao Q, He R, et al. The prevalence of Epstein-Barr virus infection in different types and sites of lymphomas. Jpn J Infect Dis. 2010;63(2):132-5.

34. Bahnassy AA, Zekri AR, Asaad N, El-Houssini S, Khalid HM, Sedky LM, et al. Epstein-Barr viral infection in extranodal lymphoma of the head and neck: correlation with prognosis and response to treatment. Histopathology. 2006;48(5):516-28.

35. Dirnhofer S, Angeles-Angeles A, Ortiz-Hidalgo C, Reyes E, Gredler E, Krugmann J, et al. High prevalence of a 30-base pair deletion in the Epstein-Barr virus (EBV) latent membrane protein 1 gene and of strain type B EBV in Mexican classical Hodgkin's disease and reactive lymphoid tissue. Human pathology. 1999;30(7):781-7. 